\title{
Innovation, Habitus, and Heritage: Modeling the Careers of Cultural Forms Through Time
}

\begin{abstract}
Since the 1990s, folklorists have become more deliberate in their use of the concept of heritage, with the term now standing at the center of our theoretical and policy debates. Heritage is both a phenomenon in the world that folklorists think about and a concept that we think with. In this article we build on classic and recent work, presenting an ideal type model of heritage that locates it within the flow of time and in relationship to other modes of culture-particularly innovation and normative culture or, in a somewhat different framework, habitus. The heuristic offered emphasizes the different degrees of metacultural salience characteristic of a cultural form in a particular social, cultural, and historical context and aims to supplement critical perspectives that are particularly focused on formal heritage policies.
\end{abstract}

SINCE THE 1990s, folklorists have become self conscious and more deliberate in their use of the English language term "heritage." In earlier periods the word was regularly used rather casually with a taken-for-granted patrimonial meaning. ${ }^{1}$ Today the term-often qualified with the prefix "cultural" and differentiated into "tangible" and "intangible" modes-is a matter of theoretical debate and policy significance. Even as it may be coming to share the spotlight with newer "slogan concepts" such as resilience, heritage is a phenomenon that is now ubiquitous in the larger social worlds that folklorists study and it is prominent among the concepts with which we work. ${ }^{2}$ Said differently, heritage is both something that folklorists think about and a concept that we think with. In this article, we first evoke some current 
thinking on heritage in English-language folklore studies. From there we will go on to present a complementary model of heritage that locates it within the flow of cultural history and in relationship to other aspects of culture. Cultural heritage-that which is shared-is often paired with cultural property-that which is not shared-with the two notions comprising something like the opposite sides of the same coin. Here we describe a model in which heritage is instead situated in relation to two other modalities of culture: innovation and habitus. We use the term habitus somewhat loosely here and it is not necessary to adopt this concept as articulated, for instance, by Marcel Mauss (1979) or differently by Pierre Bourdieu (1994) to engage our model. We touch first on concepts of heritage, returning to these other modes of culture below.

American folklorist, performance studies scholar, and museum curator Barbara Kirshenblatt-Gimblett has characterized heritage as "the transvaluation of the obsolete, the mistaken, the outmoded, the dead, and the defunct" $(1995,369)$. She goes on to emphasize the role of exhibition and other performative modes in giving heritage forms a second life. Such exhibitions can happen in museums, but also take many other forms, including festivals, ethnographic description, and archiving. Discussing heritage further, Kirshenblatt-Gimblett's now canonical treatment notes:

My argument is built around five propositions: (1) Heritage is a mode of cultural production in the present that has recourse to the past; (2) Heritage is a "value added" industry; (3) Heritage produces the local for export; (4) A hallmark of heritage is the problematic relationship of its objects to its instruments; and (5) A key to heritage is its virtuality, whether in the presence or the absence of actualities. $(1995,369)$

Kirshenblatt-Gimblett's model of heritage is particularly suited to contexts such as cultural tourism, museum display, and salvage ethnography where past/present disjunctures are often prominent. In her more recent work on heritage, she has tracked the ways that global heritage initiatives have the effect of converting local cultural diversities into a paradoxical global commons in which the local is made available for extralocal consumption and economic appropriation out of a global public sphere that heritage policy helps construct (Kirshenblatt-Gimblett 2004, 2006).

American folklorist Dorothy Noyes has built upon KirshenblattGimblett's model, stressing the role that heritage plays in negotiating 
modernity, including in identity politics and in political economy. Whereas the folklorist's concept of folklore provided a medium for political recognition within modernizing nation states, Noyes notes how heritage represents a preferred form of economic development under globalization. Noyes has stressed the negative consequences of heritage policies when pursued as identity or economic development strategies.

When a collective tradition is reduced to an emblem of identity and/or a tourist attraction, it becomes less available for all the other uses of tradition: to socialize children, to learn and practice skills, to compete for status, to maintain memory, to provide entertainment, to worship divinity, to negotiate conflict, to contemplate the meaning of life. Complex performance traditions evolve in societies with scarce resources to serve a range of purposes. They are especially important in helping people to negotiate rapid social change. When they are removed from everyday use by heritage protection, the foundations of the community can be destroyed instead of strengthened. (2014)

For further exploration of heritage's negative externalities, we particularly recommend Noyes's volume Humble Theory (2016). ${ }^{3}$

Work in critical heritage studies by Kirshenblatt-Gimblett, Noyes, Valdimar Tr. Hafstein (2012, 2018), Regina Bendix (2018; Bendix, Eggert, and Peselmann 2013), Kristin Kuutma (2016), and others on whom we draw emphasizes the praxeological dimension and places a special focus on the social construction of heritage. The theoretical work we aim to contribute to here builds on this agent-centered approach to situate heritage (as one mode of cultural life) in relationship to two other manifestations of culture-innovation and the normative culture that is fundamental to everyday life across societies. Existing critical heritage theory discusses in detail the complex implications of heritage processes but less directly addresses the place of heritage as a cultural mode in the everyday lifeworld as experienced by individuals and groups through time. Inspired by both existing theories of heritage and rich ethnographic work on life in heritage-filled communities, our model is an effort to work toward a treatment of heritage as a kind of culture that people live with everyday. We write in a provisional-but-theoretical idiom, but we are mindful of our ethnographic experiences and those of diverse colleagues in our field. ${ }^{4}$ 


\section{Culture and Metaculture}

The scholars mentioned here are just a few among numerous Englishspeaking folklorists and ethnologists theorizing the social status and ramifications of heritage. ${ }^{5}$ Engaging and extending this work requires understanding the German-American culture concept that is a key inheritance of American folklore studies via Franz Boas and his students. As suggested by the work of Kirshenblatt-Gimblett and others theorizing heritage, an associated concept of metaculture-that is cultural expressions or representations that are about cultural expressions or representations-is also necessary.

For those new to such discussions, we note that the word Boasian is generally used to refer to scholarly work attuned to research questions, findings, methods, principles, and theories associated with a research line in American anthropology (inclusive of American ethnology) and folkloristics pursued by Franz Boas and his students (Jackson 2000, 2010; Stocking 1998; Darnell 1973, 2001). Many articulations of the Boasian culture concept are available to us. Because of its succinct relevance to a concept of metacultural awareness, we turn here to a formulation offered by Boas's student Alfred L. Kroeber in his 1948 text Anthropology: Race, Language, Culture, Psychology, Prehistory. Regarding culture, he wrote: "Now the mass of learned and transmitted motor reactions, habits, techniques, ideas, and values-and the behavior they induce-is what constitutes culture" $(1948,8)$.

In the same work, Kroeber addresses the dynamics of unconsciousness and consciousness of culture. On the first, he argues: "The quality of unconsciousness seems to be a trait not specifically limited to linguistic causes and processes, but to hold in principle of culture generally" (245). While linguistic phenomena, such as grammatical gender, had provided a generative domain for Boasian cultural theorizing (cf. Boas 1911, 63-70; Silverstein 1979), Kroeber importantly is flagging the general capacity of cultural phenomena to manifest relatively low levels of individual and shared awareness. While in Boasian ethnology, this quality of culture had a number of ramifications beyond our scope here, we note that it is this same phenomenon that also underpins our vast literatures on social norms and the interaction order (Goffman 1963, 1971). They are at issue, for instance, in the breaching experiments that we most often associate with the work of Harold Garfinkel (1991). Performance-oriented folkloristics inherited interests in the relative degree of consciousness 
of cultural phenomena down several lineages, including the fundamentally Boasian ethnography of speaking (Boas 1911 as reflected in Hymes 1974), interactional sociology and social psychology (Goffman 1974 as reflected in Bauman 1975), and Roman Jakobson's poetics (Jakobson 1960 as reflected in Shuman and Hasan-Rokem 2012; see also Jakobson 1980). ${ }^{6}$

As in psychoanalysis and ethnomethodology, Boasian ethnology attended to the movement from relatively unconscious to relatively conscious. Kroeber continued: "A custom, a belief, an art, however deep down its springs, sooner or later rises into social consciousness" $(1948,245)$. In the Boasian framework, this could happen in a variety of ways emerging from both extraordinary and everyday life experiences, for instance, in the lived experience of rapid cultural change or through diverse, normal experiences of intercultural contact (e.g., travel, intermarriage, pilgrimage, ethnography, or migration). In the American approach rooted in Boasian concerns, we also see the ways that individual variance in reflective disposition shapes intrasocietal variation in metacultural awareness. We recognize this in the key interlocutors who often star in American folkloristic ethnography. Like Packy Jim McGrath, the subject of Ray Cashman's recent book on Irish worldview, such consultants reel us in with their higher than usual awareness of, and capacity to critically reflect upon, their cultural surround (Cashman 2016). ${ }^{7}$

If metaculture is cultural expressions or representations that are about cultural expressions or representations, the fullest available treatment of metaculture, to our knowledge, can be found in Greg Urban's (2001) Metaculture: How Culture Moves Through the World. Our arguments here are particularly indebted to Urban's theoretical work. We do not fully unpack the concept here, instead introducing it just enough to frame our perspective on heritage as a kind of metacultural process or state recognizable through its co-occurrence with elaborated metacultural discourses. Heritage discourses and practices are canonical instances of metaculture. As Urban writes: "judgments made by natives about similarities and differences-continuity with the past and change-are part of what I will call metaculture, that is, culture that is about culture" $(2001,3){ }^{8}$

In building on the contemporary concept of metaculture carried forward from this classic theory of culture, the model we introduce here emphasizes the theme of relative metacultural awareness present in individuals and that can be hypothesized for typical individuals 
within collectives. This awareness has a snapshot character in time and focuses in any given instant on a particular cultural form, expression, value, or complex. Theoretical work on metacultural awareness owes much to scholarship on metalinguistic awareness, work which has in turn shaped understandings of linguistic ideologies, including work on language loss that is relevant to the kinds of heritage phenomena of concern here (Silverstein 1981; Irvine 2012).

\section{Innovation/Habitus/Heritage: A Heuristic}

The kinds of theories of heritage that we have evoked are complementary to each other, touching on different aspects of a multifaceted whole. Our model is offered in this spirit of complementarity with the hope of supplementing constructively critical perspectives that
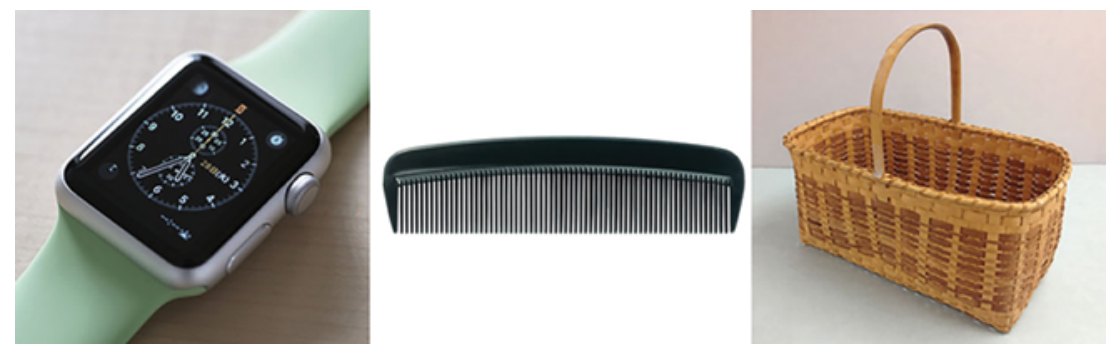

FIGURE 1

To evoke the three modalities of culture under discussion, we point to three examples from the material culture of North America. Left is an Apple Watch from 2015, a (then) innovative technology that was, for a time, the focus of considerable metacultural discourse (face-to-face conversation, press articles, reviews, etc.). Center is a plain man's pocket comb, an object that is generally taken for granted. Neither new nor markedly old, it exists in the realm of everyday practices without being the focus of much attention or discussion outside of specialist contexts such as barber shops. At the right is an Eastern Cherokee white oak splint basket (from the collections of the National Museum of Natural History). While baskets of this type among the Cherokee were initially innovations adopted from Europeans after contact, such baskets today have passed through a period of everyday normality to become emblems of Cherokee cultural heritage. Community heritage initiatives help celebrate, promote, and preserve such basketry. Apple Watch image by Yasunobu Ikeda via Flickr (licensed CC BY-SA 2.0). Black Plastic Pocket Comb image by Crisco 1492 via Wikimedia Commons (licensed CC BY-SA 4.0). White Oak "Market Basket” by Eastern Band Cherokee Basket Maker Agnes L. Welch, ca. 1961, from the William C. Sturtevant Collection, Department of Anthropology, National Museum of Natural History, Smithsonian Institution. WCS560. Image by Jason Baird Jackson. 
are particularly focused on formal heritage policy. Our model situates heritage as one of three "ideal type" manifestations of culture, placing it alongside innovation (i.e., those aspects of culture overtly marked as new) and habitus (i.e., culturally derived and individually embodied dispositions, norms, and taken-for-granted practices) (Figure 1). ${ }^{9}$ All three are here situated in relation to the passage of time in the flow of cultural history. We do not frame the model in this way here in this article, but it is also possible to treat these three modes of culture ethnologically or geographically, in relation to movement in space rather than to time. This prospect suggests the ways that our model is intended as a contribution to the broader renewal of historic-geographic, historical, and comparative approaches in a plural tradition of folklore studies that remains attentive to the tasks of performance ethnography (for related arguments, see Jackson 2013a).$^{10}$

The scheme that we present here was developed initially by Jackson and Müske. Zhang's $(2014,2018)$ ethnographic work on heritage practices in China has further enriched our thinking relative to the proposed model (Figure 2). Horizontal movement to the right represents time's passage. Relative degrees of cultural self-consciousness are represented by height or depth relative to the centerline.

Cultural forms positioned above the centerline are ones manifesting some relative degree of collective self-consciousness. This is manifest in their being the focus, for instance, of significant metacultural discourse. An example from Zhang's work are a type of fortress-like, monumentally-scaled, rammed-earth domestic buildings found in a rural part of China's Fujian province. Formerly just a local home type, these buildings, known now as the Fujian tulou, are marked as cultural heritage properties from the global to the local levels and are the subject of much self-conscious discourse as well as vigorous economic, political, and legal activity (Figure 3) (Zhang 2014, 2018; UNESCO 2018). The Patum of Berga, as documented by Noyes (2003, 2016, 337-379), has similarly become a matter of ever-greater self-consciousness as it has become entwined in what Bendix and her colleagues have characterized as "heritage regimes" of an extralocal sort (Bendix, Eggert, and Peselmann 2013).

Cultural forms positioned below the timeline are ones that have faded into the social and cultural background. They are unremarkable in the literal sense that they generate little metacultural commentary on their status. Whether in the form of the cultural traits studied by Boasian ethnologists or as Geertzian "local knowledge," culture of this sort has long been the primary concern of American cultural 


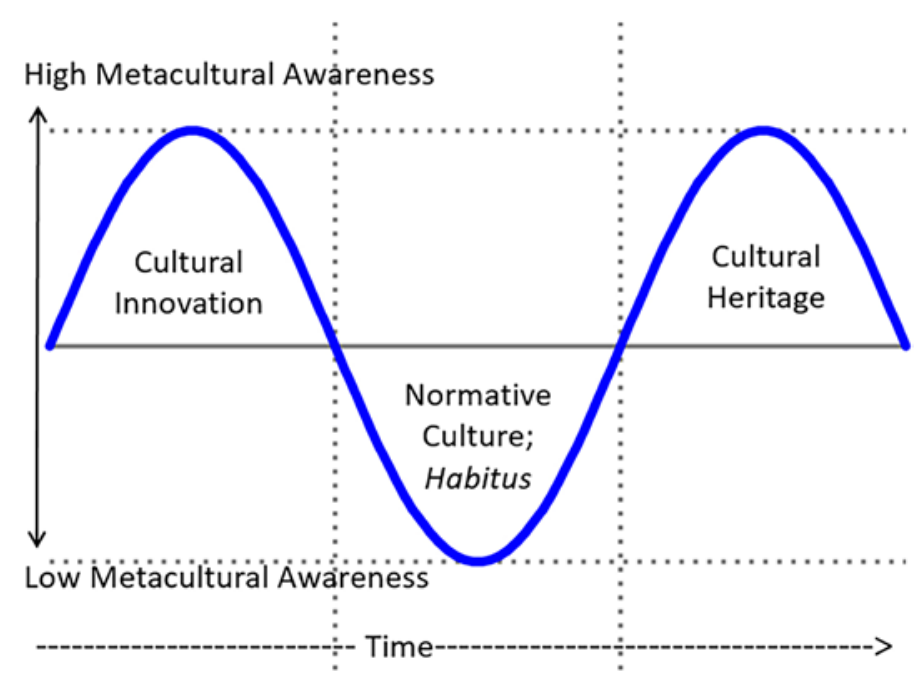

FIGURE 2

A heuristic diagram characterizing innovation, normative culture, and cultural heritage over time and in relationship to metacultural awareness. Figures 3-5 offer examples situated at different points along the continuum of this model.

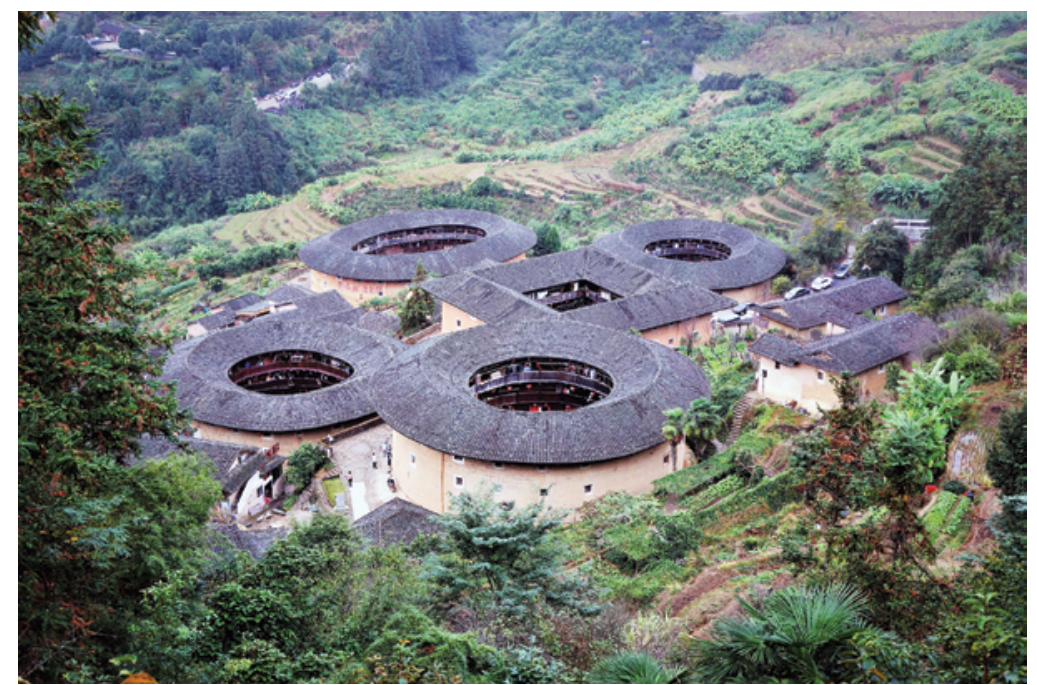

\section{FIGURE 3}

An example of cultural heritage that would be situated on the right above the center line in Figure 2, "[Fujian Tulou] are inscribed as exceptional examples of a building tradition and function exemplifying a particular type of communal living and defensive organization, and, in terms of their harmonious relationship with their environment, an outstanding example of human settlement." (UNESCO 2018). Fujian Tulou were inscribed on the UNESCO World Heritage List in 2008. Image by Peter Dunne via Flickr (licensed CC BY-NC-ND 2.0). 


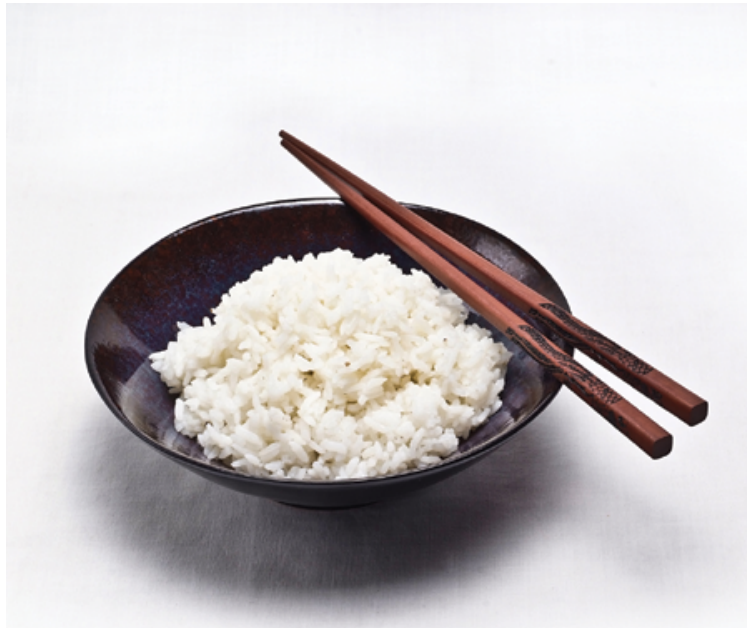

FIGURE 4.

An example of normative culture or habitus that would be situated below the center line in the middle of Figure 2, an everyday bowl of rice-neither innovation nor heritage. Image by International Rice Research Institute (IRRI) via Flickr (licensed CC BY-NC-SA 2.0).

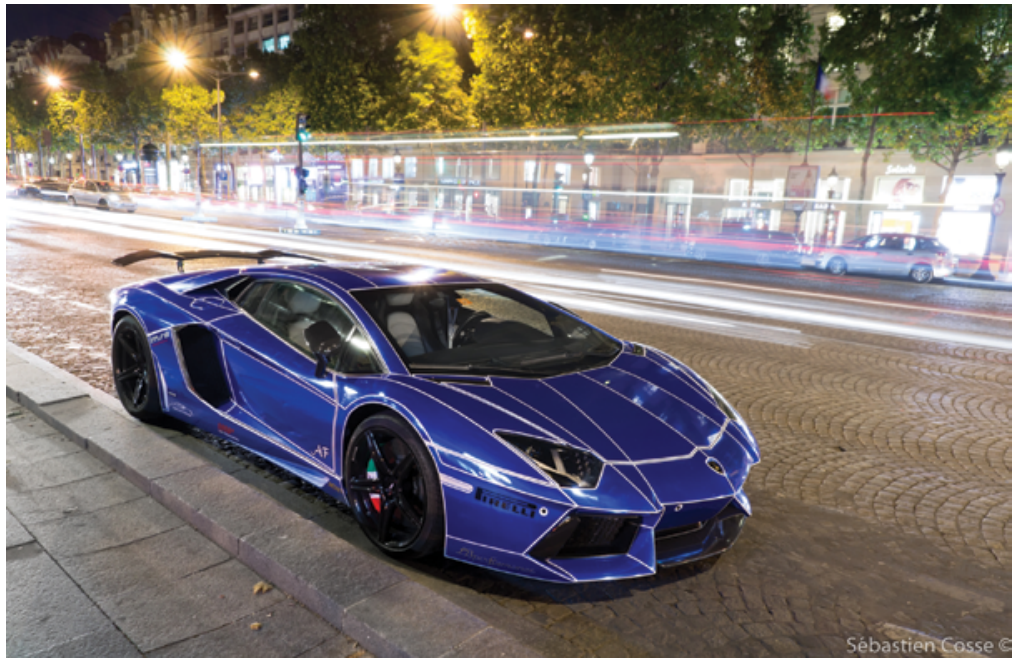

\section{FIGURE 5}

Situated to the left above the center line in Figure 2, cultural innovations take many forms, including fads in fashion, technology, and design. Decorated with reflective tape, so-called "Tron cars" (resembling vehicles in the 1982 movie Tron) captured the imagination of young adults in urban China as well as Western journalists around 2014 (Dias 2014). Image by Sebastien Cosse via Flickr (licensed CC BY-NC-ND 2.0). 
anthropology. It is also a focus for much contemporary European ethnology, with its current theorized passion for quotidian practices (SIEF 2014, 2017). Taken for granted assumptions, everyday routines, commonplace commodities, norms of conventional conduct, Maussian "body techniques," and so much else in our lives and in the lives of all people have this character (Figure 4). As American ethnology/cultural anthropology and European ethnologies have regularly demonstrated, this core of culture has a low degree of self-consciousness but this does not mean that it is unconscious in the psychoanalytic sense. Ethnographic inquiry, the necessities of childrearing, cross-cultural travel, among other techniques, have long helped individuals and groups gain a reflexive sense about their everyday lives. Still, the modes of culture positioned below the horizontal line are distinct in that they are separate from two other modes of culture that do especially attract heightened metacultural awareness and discourse.

In this treatment, the two aspects of culture seemingly most divergent in other ways are shown to share a key quality-metacultural prominence. New technologies, new social innovations, and the latest fads and fashions, along with much else marked as "new," are commonly matters for public discussion and debate (Figure 5). Similarly, obsolete technologies, moribund customs, and longstanding-but-disappearing ways of life, and eroding values are also often matters for public discussion and debate. ${ }^{11}$ In both modes, metacultural prominence correlates with cultural self-consciousness and is made manifest in varied discourses and social interventions.

While heritage is a special concern of folkloristics-an outgrowth of its status as a kind of recasting of our nominal object (i.e., folklore), folklorists also have a tradition of studying innovation. We see this at the core of the Boasian version of the historic geographic method, with its concern for the adoption-or-not of diffused cultural traits as well as with the historical invention of new cultural forms (Boas 1982, 281-89, 290-94; Lowie 1940, chapter 20; Kroeber 1948, chapters 8-14). While American folklorists have not tended this tradition particularly well, it is fundamental today in the social science-turned-business literature on innovation diffusion, a literature in which social difference-for example, early adopters versus laggards-has taken the place of spatialized cultural groups (Rogers 2003; Gladwell 2002).

In a different way, Noyes's (2016) work on "hardscabble academies" points to the social contexts in which vernacular innovations arise and are adopted. In general, however, concern for innovation 
has grown less pronounced in autonomous American folkloristics as it has drifted from its ethnological roots. There are always exceptions to any generalization, though. We acknowledge that we can see one kind of renewed interest in new cultural forms in, for instance, contemporary American folklore work on new media genres (Blank 2008). Think, for instance, the folkloristics of cleverly captioned photographs (a.k.a. image macros, memes) circulating in social media.

In the ethnological culture history framework informing this article, innovation is, for instance, at the center of revitalization movements as well as being fundamental to the local adoption of diffused cultural forms (Harkin 2007). It is also a key motif in the Americanist biographical tradition, as reflected in the life histories of innovators in "traditional" societies as well as the stories of individuals who so often experienced missionization, colonization, migration, and other modes of radical cultural change (cf. Brandes 1979). ${ }^{12}$ Culture brokers, innovators, and those whose personal stories center on significant levels of dramatic social change-three prominent types of ethnographic consultants-all generally share higher-than-average levels of metacultural awareness relative to both that which is new and arriving and that which is old and departing (Casagrande 1960).

The vast space below the abstract self-consciousness borderline has been referred to and discussed in a number of ways. In Boasian approaches, it is the main share and normal mode of culture. It is also recognizable as the embodied cultural practice that Mauss, and Bourdieu after him, characterized as habitus (Mauss 1979; Bordieu 1994). This semiconscious and generally unquestioned (in everyday life) mode of culture is built up out of cultural content that originates ultimately in innovation. Innovation from this perspective includes the modern sense of invention, but also includes other quite varied forms of cultural change, both the intentionally directed and seemingly random. While every cultural form begins at some point in space and time, innovations usually appear in individual lives and collective experience having circulated from elsewhere. To adopt a diffused cultural expression is thus also to innovate, as the contemporary literatures on innovation adoption stress (Rogers 2003).

As those of us who were children prior to the availability of mobile telephones or the public internet have witnessed, these are model innovations in the sense described here. For younger adults and children in most parts of the United States-individuals who have never lived without them-both are rapidly moving into the realm 
of unremarkable everyday culture. Everyday, all around the world, people are experiencing the normalization of previously innovative cultural forms, whether those innovations began as inventions (e.g., invitro fertilization in the UK) or importations (e.g., sushi in the urban U.S.).

Innovations such as robotics, artificial intelligence, self-driving cars, nanomaterials, vat-grown hamburger, or weaponized "insect" drones are marked for conscious discussion (these are examples recently under discussion in the United States or Europe) because they are new and are entering the cultural system, often causing some anxiety in the process. Heritage is marked for conscious discussion because it is old, is valued favorably by someone, and is perceived or feared to be leaving the cultural system (Jackson 2007). Innovations are at the beginning of their cultural careers, while heritage is seen as, or feared to be, at the end of its time as lived cultural practice.

Here we intersect with the core of Kirshenblatt-Gimblett's model (1995). She speaks of heritage giving cultural forms a second life after they would otherwise become obsolescent. This could conceivably be a long-term fate. Alternatively, the heritage phase could be relatively brief-something like a period of mourning prior to the complete loss of its object.

To think through the distinction that we raise here, consider the basket-making practices found today in some Native American communities and in Japan. With baskets no longer widely used as tools of physical labor, basketry was, in some but not all possible contexts, reframed as an important expression of cultural heritage, with linkages to art markets, tourism, personal and museum collecting practices, and the expression of local (in Native American contexts) or national (in Japan) identities. This has been a multigenerational and ongoing project in these societies, with changes developing within the heritage period, as with the decline of heritage baskets sold to tourists in Native American societies and the rise of heritage baskets that are understood as works of fine art. Contrastively, folklorists around the world have found themselves documenting and heralding the work of the "last" practitioner of a once-vital expressive form or culturally-rooted custom. While such "lasts" are not always actually the last, sometimes they are. Folkloristic documentation, celebration, and lamentation of obsolete-to-moribund heritage can happen in a very brief period of time. Many folklorists have been told by earnest, elderly interlocutors, "No one wants to learn it." Such folklorists have 
sometimes been surprised when someone does want to learn it, but some folklorists have also seen prophecies of disappearance proven true.

Importantly, not all culture forms experiencing obsolescence are recast as heritage. The elders among the Yuchi people with whom Jackson has worked as an ethnographer were deeply committed to the revitalization of their unique "heritage language" but had no desire to return to the practice of hauling home muddy drinking water in barrels in wagons from distant sources. In every society open to heritage-making, doing so is a selective process unfolding within particular regimes of value.

Most interesting to contemplate and follow, are instances in which heritage comes to be transformed back into habitus. Heritage endeavors, particularly locally initiated and controlled preservation efforts in small scale, community contexts have moved in this way, often intentionally. A child raised in the midst of a successful cultural revival can perceive a renewed state of vitality not as a persistent heritage intervention but as a local norm (Figure 6). ${ }^{13}$

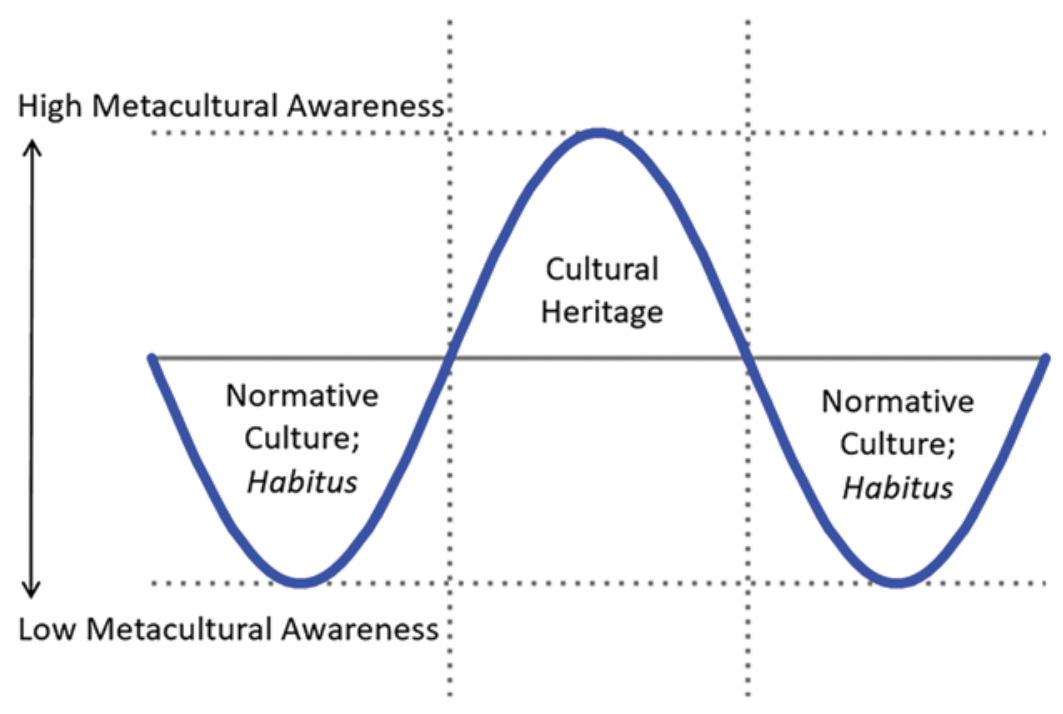

Time

FIGURE 6

A version of the heuristic diagram evoking the renormalization of heritage. Note that the abstract model is drawn like a wave, but there is no necessity that cultural changes be either rhythmic or gradual. In this case, a revitalized and renormalized heritage item might persist with stability in an ongoing way. 
When everyday culture is born again out of heritage work, the wave line of heritage goes back below the self-consciousness line. While we may think that such a transformation is relatively rare from the perspective of a narrow definition of heritage, this is a fundamental effect of many successful "revitalization movements" as well as of diverse cultural "revivals." When Jackson once expressed anxiety about the seeming unidirectional quality of her model of heritage, Kirshenblatt-Gimblett was quick to point to her own work on klezmer-the musical genre rooted in the cultural history of Eastern European Jews (1998). She has tracked a recent postheritage (postconservatory) stage characterized by increased innovation and what we might call renormalization. This more recent period of renewed vitality followed a period of strict preservationist activity. This conservationist period logically followed the genocide, destruction, and displacement of the Holocaust (1933-1945) and the Second World War (1939-1945)-historical events that had effectively ended the kind of communal life in which the music previously flourished..$^{14}$

\section{Conclusion}

The model we offer here has been visualized in the form of a wave, but it is important to recognize that this is a heuristic for interpretive work not data from an experiment in social physics. The aim of the visualization is to capture aspects of cultural historical processes that we think are, at some level of generality, reoccurring in the social worlds that folklorists and ethnologists both study and live within. In any particular "real world" case, the line charting the career of a cultural form and people's metacultural relationship to it would be irregular and distinctive. For a great many parts of the cultural worlds in which we all live, the forward-moving line long ago sank below the consciousness line. Only a small number will ever rise above it again. Especially for those exhausted by the expressions of heritage that we are already managing, safeguarding, preserving, reviving, monetizing, fighting over, and so forth, this fact is perhaps a source of relief. Surely no one would want to give a second life to the entire global repertoire of interconnected human practices and values from both past and present. Heritage is salient because it is selective and, as Kirshenblatt-Gimblett stresses, a "mode of cultural production in the present" (1995, 369) and is thus an outgrowth of present-day preoccupations. 


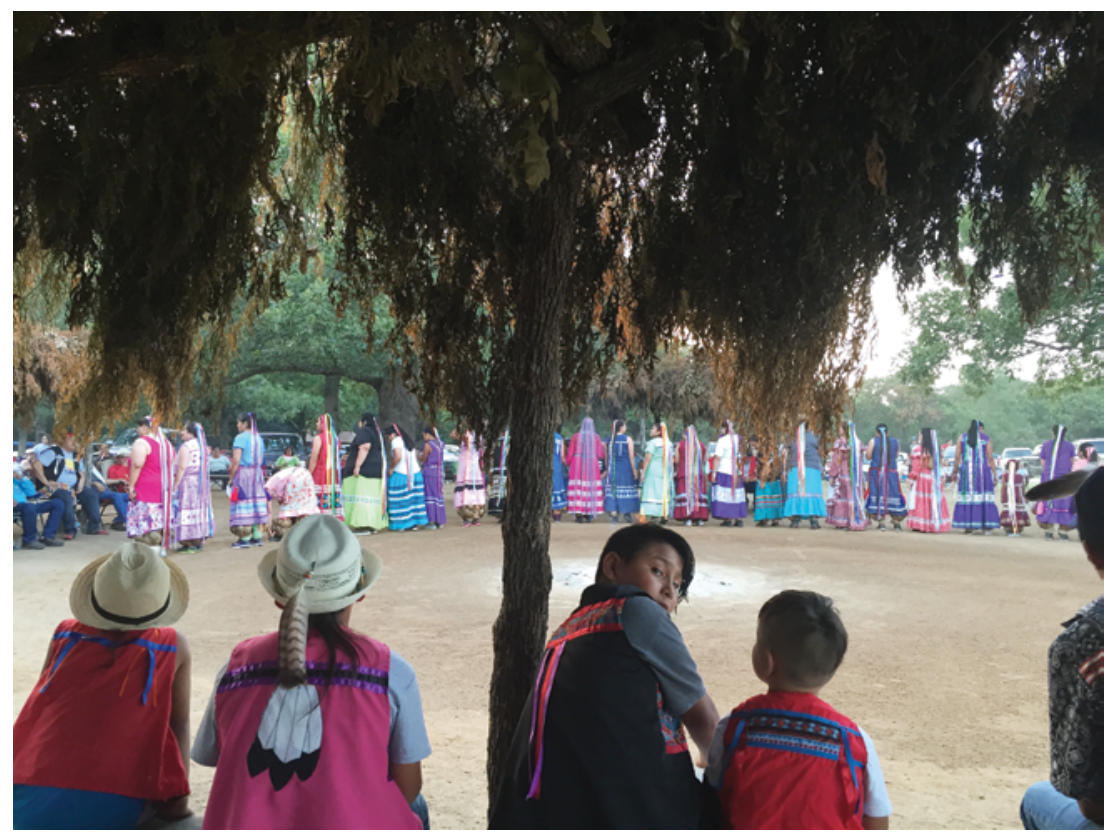

FIGURE 7

Reestablished in their community in 1994, many of the younger women and girls of the Duck Creek Ceremonial ground shown here dancing the Yuchi Ribbon Dance in June 2016, have never known the absence of this important ceremonial dance. A self-conscious effort made by their elders laid the groundwork for a (re-)new(-ed) normal. Photo by Jason Baird Jackson.

In closing, we note again that our heuristic is offered as a complement to existing theorizations of heritage. Work by Jackson and others in Native American communities has suggested the value of such a complementary approach (Figure 7). In such communities, there is a tremendous amount of heritage activity (the English word heritage is often explicitly used for it) but this activity-in contrast to circumstances in various other parts of the world-is not driven by nonlocal tourists, political agendas, scholarly programs, or economic development schemes, even as such phenomena are certainly also present in Native North American communities. An approach that is compatible with such grassroots kinds of heritage endeavors and that can easily attend to situations in which these activities achieve the goals set for them by community heritage workers seems valuable to us. A model that includes innovation and everyday normative culture helps in several ways. Among these is fostering the recognition that innovations are often leveraged in the service of heritage and that 
heritage programs and initiatives themselves are often innovations and not just interventions..$^{15}$

The use of the latest digital technologies such as smart phone apps for indigenous language revitalization efforts provides an increasingly widespread illustration from our own moment. Soon such things will probably seem normal. Our work here is offered in the hope of better accounting for the nature of such shifting heritage situations outside of the UNESCO heritage sphere. We also have aimed to suggest the value of reanimating older ethnological findings and frameworks in the service of current scholarly tasks. Folklore studies, European ethnology, and cognate fields would benefit, we hold, from a reengagement with their own heritage as well as renewed attention to such social, cultural, and historical phenomena as invention, innovation, diffusion, the nature of everyday and quotidian cultural forms, revitalization, revival, endangerment, obsolescence, traditionalization, and grassroots heritage-making projects.

\section{Indiana University}

Bloomington

\section{University of Freiburg}

Freiburg, Germany

George Mason University

Fairfax, Virginia

German Abstract: Seit den 1990er Jahren wird das Konzept Kulturerbe in den volkskundlichen Kulturwissenschaften zunehmend reflektiert. Der Begriff ist zentral für heutige Theorie- und Policy-Debatten im Fach: Kulturerbe ist sowohl ein Phänomen über das als auch ein Konzept mit dem KulturwissenschaftlerInnen nachdenken. In diesem Artikel entwerfen wir, aufbauend auf klassischen und aktuellen Studien, ein idealtypisches Modell von Kulturerbe, welches Kulturerbe zeitlich und in Relation zu anderen kulturalen Modi anordnet-insbesondere zu Innovation und kulturellen Normen (in anderer theoretischer Lesart auch Habitus). Die vorgeschlagene Heuristik betont den metakulturellen Charakter einer kulturellen Form und die unterschiedlichen Grade der Bewusstheit in einem bestimmten sozialen, kulturellen und historischen Kontext und möchte kritische Perspektiven auf Kulturerbe-Politiken ergänzen. 
CHINESE ABSTRACT: 自 20世纪90年代以来, 民俗学者对遗产概念的使 用变得更具思考性, 现在这一术语已经成为我们理论和政策辩论的 焦点。遗产即是民俗学者思考的全球现象, 也是我们用于思考的一 个概念。本文以经典研究和近期成果为基础, 提出一个遗产的理想 型模型。该模型把遗产置于时间之流中和与其他文化模式的关系之 中，特别是与创新和惯常文化的关系之中，惯常文化在某种不同的 框架里也被称为惯习。本文的启发性在于强调在特定社会、文化和 历史语境中文化形式的元文化程度是不同的, 本文也意在补充那些 侧重于官方遗产政策的批判性观点。

\section{Acknowledgements}

Versions of this article were presented at the Sixth Forum on China-US Folklore and Intangible Cultural Heritage, Guizhou, China, April 13-14, 2015; the 2016 American Folklore Society Meeting, Miami, Florida, USA; to the Institute of Literature of the Chinese Academy of Social Sciences, May 24, 2018, Beijing, China; and to the University of the Chinese Academy of Social Sciences, May 25, 2018, Beijing, China. The authors offer special thanks to the receptive and engaged audiences gathered on these occasions, particularly An Deming who hosted a rich discussion of the paper among the folklorists at the Chinese Academy of Social Sciences. For initially fostering the ideas presented here, the authors also thank Regina Bendix and the other leaders of the Deutsche Forschungsgemeinschaft Interdisciplinary Research Group on Cultural Property (2008-2014). Jackson served as Commentator for the project, visiting the research group in Göttingen in 2010. Müske served a project Researcher during its first funding period (20082011). Zhang contributed in essential ways to the project once it was initiated and was essential to its calibration for, and presentation to, various heritage-minded Chinese audiences. Finally, we express appreciation here for the efforts undertaken on our behalf by two anonymous Journal of Folklore Research reviewers and by the journal's editorial and production staff.

\section{Editorial Note}

A version of this paper appeared initially in Chinese as: Jason Baird Jackson, Johannes Müske, and Lijun Zhang. 2019. “创新、惯习与遗 产：关于文化形式历史发展进程的理论模型” [Innovation, habitus, 
and heritage: Modeling the careers of cultural forms through time.] 民间文化论坛 [Folk culture forum] 254: 5-15. The editorial staff of the Journal of Folklore Research join the authors in expressing appreciation for the work of our partners at Folk Culture Forum, particularly editor An Deming.

\section{Notes}

1. For the ways that folklorists have iteratively debated, formulated, described, and critiqued the concept of heritage and how heritage debates relate to earlier ones around "folklore" and newer ones related to, for instance, "resilience," see Noyes (2016). The literature on heritage is now vast in folklore studies, ethnology, and neighboring fields. The field of inquiry is also international in scope, with particular strengths in the three scholarly languages represented by the authors (English, German, and Mandarin Chinese). We regret that we can only draw upon a small portion of this literature in this project. Hafstein (2012) provides a survey for folklore studies; a German introduction to the concept and field is provided in Tauschek (2013). Those seeking an introduction to heritage studies in China can begin with An and Yang's English-language contextualization of folklore studies in China since the late 1970s (2015). For the closely related concept of cultural property, see Skrydstrup (2012). See also Note 3, below.

2. "The slogan-concept is an abstraction that seems to validate concrete realities, the name of a purportedly eternal idea used to launch a time-specific project, a tent providing shelter to actors coming from all directions" (Noyes 2016, 412). For "slogan concepts" and for "resilience" as an example, see Noyes (2016, 410-37).

3. In addition to Noyes's writings, we point in particular to the work of Kristin Kuutma (2013, 2016) and that of Regina F. Bendix (2018), including the rich body of work produced by the cultural property research group that Bendix led (DFG Interdisciplinary Research Group on Cultural Property 2018). We also recommend the overview of heritage scholarship offered by Icelandic folklorist Valdimar Tr. Hafstein in A Companion to Folklore (2012). Drawing upon our international field and his own important scholarship, he does an excellent job of synthesizing the critical folklore studies literature on heritage theory and policy (2012, see also Hafstein 2018). For illustrative ethnographic case studies exploring the local impact of formalized heritage policies, see Foster and Gilman (2015) and Zhang $(2014,2018)$. For case studies of state-level heritage policies and practices, see Bendix, Eggert, and Peselmann (2013) and Maags and Svensson (2018).

4. Even the seemingly simple expression "our field" is complex, as each coauthor operates within, and feels attachment to, multiple and differing disciplinary positionalities in multiple local, national, regional, international, and interpersonal social network contexts. We sometimes write here as if folklore studies is a coherent, unified discipline neighboring to, but distinct from cultural anthropology, ethnology, and adjacent fields, but we are very much aware that this is a tactical simplification and also a misrepresentation of a much more complex landscape, past and present. Situated in multiple provincial contexts but aspiring to enact an aspirational international scholarship, we are uncomfortably aware, 
for instance, of how much relevant scholarship (in English and many other languages) we are failing to engage in this effort. For one of several useful evocations of the plural state of the fields in which we are engaging, see Bendix (2003).

5. In a 2011 contribution to the Journal of Ethnology and Folkloristics, Markus Tauschek offered an earlier reflection on heritage theory in relationship to metaculture and a biographical approach to cultural forms. Among his concerns though is the belief that tracking the transformation of habitus into heritage implies a "teleological 'historical trajectory"” $(2011,57)$. As discussed later in this article, we have endeavored to show that heritage can be converted into habitus and not solely the reverse.

As work on our article unfolded slowly over a period of many years, Michael Dylan Foster was pursuing an important ethnographic project on the impact of national and international heritage interventions on local ritual masking practices in rural Japan, particularly on the visiting diety customs found on the island called Shimo-Koshikijima. Foster (2017) draws on many of the same sources that inspire our work here to both interpret his case but also to offer a conception of metaculture compatable with, but distinct from, the one that we use in this article. Foster is working with a conception of metaculture in which this term refers to transcultural phenomena (such as, for instance, UNESCO heritage designations) whereas here we use metaculture to refer to those aspects of culture (local or translocal) that are themselves about culture.

6. Richard Bauman's work on storytelling offers a now canonical example. In accounting for the work of Texas storyteller Ed Bell, Bauman noted the way in which, over time, his storytelling performances were staged in increasingly formal settings for audiences with decreasing familiarity the local cultural contexts out of which his stories derived. Telling stories for formally constituted audiences in cross-cultural contexts increased Bell's self awareness of his storytelling practice and of the passive cultural knowledge that his stories demanded in their source context. A range of techniques were used by the narrator to recalibrate his stories for new audiences, prominent among them being the introduction of rich metadiscursive commentary. The shifts chronicled by Bauman are closely linked to the kind of increased metacultural awareness that performance provokes and that we are evoking in relation to heritage (Bauman 1986, 78-111).

7. Given American folklore studies' emphasis on excellence in expressive performance, we often see the individuals with whom we work-as their communities often also do-as "stars" relative to the exercise of their talents vis-à-vis the aesthetic or expressive practices for which they are deemed masters (i.e., "star performers"). But folklore studies, cultural anthropology, and field linguistics also have a history of recognizing "star informants"-ethnographic consultants who are particularly adept at the work of cultural and/or linguistic translation and explication across cultural difference (see Cashman, Mould, and Shukla 2011, 12; Silverstein 1981 addresses related issues). From the perspective developed in this article, star informants-but also artists who cultivate the skills needed to perform in cross-cultural settings - are often those with higher-than-typical metacultural awareness or consciousness. As Ray Cashman, Tom Mould, and Pravina Shukla note, star performers can sometimes, but need not also be (capable of being), star informants (2011, 12-14). 
8. For traditionalization as a closely related metacultural practice, see folklore studies and linguistic anthropology work cited in Jackson (2013b, 74-85, 216-18). Similarly, for treatments of linguistic and cultural "endangerment" (a related metacultural discourse about the potential "death" of linguistic varieties or cultural forms) in this perspective, see Jackson (2007) and Moore (1999).

9. Readers seeking orientation to the methodological concept of ideal type as used here are directed to the classic formulation developed by German sociologist Max Weber (1949, 89-99). A classic Chinese development of the concept inspired by Weber can be found in the work of Fei Xiaotong (Fei, Hamilton, and Wang 1992, 8). For a current assessment of ideal type methods, see Swedberg (2017). Our use of habitus owes more to the earlier formulation of Mauss (1979) than to that of Bourdieu (1994). As noted above, one need not embrace the concept of habitus to engage our model. Routines, for instance, as described by Damsholt and Jespersen (2014, 26, drawing on Ehn and Lofgren 2010) fall into this zone. Any word or words describing generally-taken-for-granted and uncontroversial cultural norms or forms or practices or techniques will work. In this article, we also characterize our formulation as a "model." For clarity, we note that the sense of model that we have in mind is heuristic, that is "a description or analogy used to help visualize something (such as an atom) that cannot be directly observed" (Merriam-Webster 2018).

10. The claim, just made, that there is a distinction between what we outline here and a space-centered ethnological analysis may require additional explanation. Both kinds of analysis - temporal change within a society and spatial patterning of difference across societies-figured prominently in the American ethnological approaches on which we draw here. While we are not here presenting ethnographic evidence from particular societies, such ethnographic (and historical) experience in particular lifeworlds most clearly informs our argument. A geographic analysis would instead focus not directly on the immediate experience of life with an innovation-turned-norm-turned-heritage phenomena in time but instead on comparative evidence from across different societies in some form of contact with each other and thereby constituting a spatial network across which cultural forms can (but do not always) circulate (through diffusion, forced acculturation, missionization, etc.) as innovations, becoming normalized (and sometimes made in turn into heritage) within particular societies. Such a project could, for instance, consider the diffusion of a practice such as the ritual use of the peyote cactus or the spead of online dating applications on mobile phones as they pass from society to society in space (a process which does have a temporality). Such a project would rely upon a great deal of comparative data whereas our arguments are mainly informed by ethnographic sensibilities. For instance, what is it like for people to talk about innovations or heritage in particular societies and how does such talk change over time as people normalize innovations or heritage-ify (disappearing) norms? A comparative account of the sort evoked but not pursued, would instead ask questions such as what kinds of metacultural discourse accompanies diffusion events across space in situations of intercultural encounter and how does the metaculture of cultural change across spatialized social contexts impact lived experience of the sort of concern to us here?

11. As an example of this dynamic we offer a case from Müske's work in Switzerland, where it has long been common for church bells to be rung on every quarter hour. This is a time signal and not for liturgic reasons, although 
the practice is not completely unconnected from its religious background. In recent times, this custom is more and more contested by some individuals living in many areas, as it is perceived as "noise." This view means that such bell ringing is vanishing as a taken for granted custom and is, at the same time, a more and more reflected-upon event in everyday culture. In 2010, the Swiss federal court judged that such ringing church bells belong to Switzerland and that there "is a public interest in maintaining this tradition" (Müske 2015, 77-78). In defense of bell ringing, the court acts as a heritage-making actor in a context in which such bells were already becoming metaculturally salient under conditions of changing cultural values and social practices.

12. Making sense of experiences of radical versus gradual social change (i.e., colonized Native American societies vis-à-vis modernized peasant ones) may partially account for differences distinguishing older American and Northern European ethnologies of innovation. Notably, the framing of innovation as a topic for scholarship in folklore studies given in this article is particularly U.S.centered. Innovation is addressed in other disciplinary settings very differently. Tini Damsholt and Astrid Pernille Jespersen's (2014) careful characterization of the ways, past and present, that innovation and everyday life intersect as conerns in Danish ethnology is an instructive illustration of this distinction.

13. Instances abound in Jackson's observations in Native North American societies. Müske offers the example of southern German Fastnacht (carnival), which has undergone a strong revival since the 1980s. Like so many "traditions," young people, but also middle-aged adults, cannot remember a period characterized by less intensity and most people think that current festival customs are hundreds of years old. Today the Fastnacht has been promoted as intangible cultural heritage by the German UNESCO Commission (folklorists have contributed to the application process and are participating on the board), and there have been arguments against such recognition since many protagonists think that the Fastnacht is not "ripe for the museum" (as the German expression goes).

14. She discussed this matter with Jackson (personal communication) during the annual meeting of the American Folklore Society in Salt Lake City, Utah held October 13-17, 2004.

15. As one thoughtful reviewer of this article observed, it might be reasonable to treat innovation and heritage not just as sharing the characteristic of metacultural prominence but as being conterminous. Put more simply, all heritage is innovation in its own moment in time. Adopted fully, a constructivist view of heritage situates it as a human-made construction in the present. While such a construction has, as most folkloristic definitions stress, recourse to the past, it can certainly be seen, from one analytic point of view, as simply one kind of innovation.

We propose, and invite others, to continue working on formulating a model that can more fully incorporate this insight. Our emphasis here retains an interest in the biography of cultural forms moving unidirectionally (but not teleologically) through time. In this context, it seems useful to differentiate between a cultural form that is being argued about because it is new, and one that is being argued about because it is old. It might be better, given our goals here, to say that it seems useful to retain differentiation for when a single cultural form that was once argued about in the context of its newness is today being discussed in the context of its oldness and concerns about its disappearance. Beyond our concern 
for difference over time, there is the hope that our conception is compatible with grassroots heritage endeavors. Those activities are human creations in the present, of course, just as UNESCO listing activities are, but an ethnography of local heritage work would be difficult to pursue with an analytic metalanguage that completely disregarded local cultural emphases on pastness. Scholars who have attempted to negotiate discussions of traditionalization-or still harder, the so-called "invention of tradition"-with members of communities invested in questions of cultural continuity have regularly faced this dilemma (Briggs 1996; Jackson 2013b, 74-85, 216-18).

\section{References Cited}

An, Deming, and Yang Lihui. 2015. "Chinese Folklore Since the Late 1970s: Achievements, Difficulties, and Challenges." Asian Ethnology 74 (2): 273-90.

Bauman, Richard. 1975. "Verbal Art as Performance." American Anthropologist 77 (2): 290-311. https://doi.org/10.1525/aa.1975.77.2.02a00030.

- 1986. Story, Performance, and Event: Contextual Studies of Oral Narrative. New York: Cambridge University Press.

Bendix, Regina F. 2003. "Translating between European Ethnologies." In TimesPlaces-Passages: Ethnological Approaches to the New Millennium, edited by Attila Paládi-Kovacs, Gyorgyi Csukas, Reka Kiss, Ildiko Kristof, Ilona Nagy, and Zsuzsa Szarvas, 371-80. Budapest: Akademiai Kiado.

- 2018. Culture and Value: Tourism, Heritage, and Property. Bloomington: Indiana University Press.

Bendix, Regina F, Aditya Eggert, and Arnika Peselmann, eds. 2013. Heritage Regimes and the State. Göttingen Studies in Cultural Property, 6. Göttingen: Universitätsverlag Göttingen. http://resolver.sub.uni-goettingen.de/purl?isbn -978-3-86395-122-1.

Blank, Trevor, ed. 2008. Folklore and the Internet: Vernacular Expression in a Digital World. Logan: Utah State University Press. https://digitalcommons.usu.edu /usupress_pubs/35.

Boas, Franz. 1911. "Introduction.” In Handbook of American Indian Languages. Bureau of American Ethnology Bulletin, 40 (1): 1-84. Washington: Government Printing Office.

- 1982. Race, Language, and Culture. Chicago: University of Chicago Press.

Bourdieu, Pierre. 1994. "Structures, Habitus, Power: Basis for a Theory of Symbolic Power." In Culture/Power/History: A Reader in Contemporary Social Theory, edited by Nicholas B. Dirks, Geoff Eley, and Sherry B. Ortner, 155-99. Princeton: Princeton University Press.

Brandes, Stanley. 1979. "Ethnographic Autobiographies in American Anthropology." Central Issues in Anthropology 1 (2): 1-17. https:/ / doi.org/10.1525 / cia.1979.1.2.1.

Briggs, Charles. 1996. "The Politics of Discursive Authority in Research on the "Invention of Tradition." Cultural Anthropology 11 (4): 435-69.

Casagrande, Joseph B., ed. 1960. In the Company of Man: Twenty Portraits by Anthropologists. New York: Harper and Brothers.

Cashman, Ray. 2016. Packy Jim: Folklore and Worldview on the Irish Border. Madison: University of Wisconsin Press. 
Cashman, Ray, Tom Mould, and Pravina Shukla. 2011. "Introduction: The Individual and Tradition." In The Individual and Tradition: Folkloristic Perspectives, edited by Ray Cashman, Tom Mould, and Pravina Shukla, 1-26. Special Publications of the Folklore Institute. Bloomington: Indiana University Press.

Cosse, Sebastien. 2015. “Aventador Oakley Design.” Flickr. https://www.flickr.com /photos/seb77181/20062211400/.

Crisco1492.2015."Plastic Comb." Wikimedia Commons.https:/ / commons.wikimedia .org/wiki/File:Plastic_comb,_2015-06-07.jpg.

Damsholt, Tine, and Astrid Pernille Jespersen. 2014. "Innovation, Resistance or Tinkering. Rearticulating Everyday Life in an Ethnological Perspective." Ethnologia Europaea 44 (2): 17-30.

Darnell, Regna. 1973. "American Anthropology and the Development of Folklore Scholarship: 1890-1920." Journal of the Folklore Institute 10 (1-2): 23-39. https://doi.org/10.2307/3813878.

- 2001. Invisible Genealogies: A History of Americanist Anthropology. Lincoln: University of Nebraska Press.

Deutsche Forschungsgemeinschaft (DFG) Interdisciplinary Research Group on Cultural Property. 2018. "Publications." Accessed May 29, 2018. http:// cultural-property.uni-goettingen.de/publikationen/.

Dunne,Peter. 2017. “China, Fujian Tulou-Nov. '17.” Flickr. https://www.flickr.com /photos/erte/38859902671/.

Ehn, Billy, and Orvar Löfgren. 2010. The Secret World of Doing Nothing. Berkeley: University of California Press.

Fei, Xiaotong, Gary G. Hamilton, and Wang Zheng. 1992. From the Soil: The Foundations of Chinese Society. Berkeley: University of California Press.

Foster, Michael Dylan. 2017. "The Challenges of Bridging Metacultural and Esocultural Perspectives on Intangible Cultural Heritage." In Glocal Perspectives on Intangible Cultural Heritage: Local Communities, Researchers, States and UNESCO, edited by Tomiyuki Uesugi and Mari Shiba, 73-88. Tokyo: Center for Glocal Studies, Seijo University.

Foster, Michael Dylan, and Lisa Gilman, eds. 2015. UNESCO on the Ground: Local Perspectives on Intangible Cultural Heritage. Bloomington: Indiana University Press.

Garfinkel, Harold. 1991. Studies in Ethnomethodology. Boston: Polity Press.

Gladwell, Malcolm. 2002. The Tipping Point: How Little Things Can Make a Big Difference. Boston: Back Bay Books.

Goffman, Erving. 1963. Behavior in Public Places. New York: Free Press. 1971. Relations in Public: Microstudies of the Public Order. New York: Basic Books.

1974. Frame Analysis: An Essay on the Organization of Experience. New York: Harper and Row.

Hafstein, Valdimar Tr. 2012. "Cultural Heritage." A Companion to Folklore, edited by Regina Bendix and Galit Hasan-Rokem, 500-19. Malden, MA: Wiley-Blackwell.

2018. Making Intangible Heritage: El Condor Pasa and Other Stories from UNESCO. Bloomington: Indiana University Press. 
Harkin, Michael E., ed. 2007. Reassessing Revitalization Movements: Perspectives from North America and the Pacific Islands. Lincoln: University of Nebraska Press.

Hymes, Dell H. 1974. Foundations in Sociolinguistics: An Ethnographic Approach. Philadelphia: University of Pennsylvania Press.

IRRI Photos. 2009. "A Bowl of Rice.” Flickr. https://www.flickr.com/photos /ricephotos/4763103718.

Irvine, Judith T. 2012. "Language Ideologies." Oxford Bibliographies. New York: OxfordUniversityPress.http://dx.doi.org/10.1093/obo/9780199766567-0012.

Jackson, Jason Baird. 2000. "Franz Boas.” Dictionary of Modern Philosophers, edited by John R. Shook, 274-76. Bristol: Thoemmes.

- 2007. "The Paradoxical Power of Endangerment: Traditional Native American Dance and Music in Eastern Oklahoma.” World Literature Today 81 (5): 37-41.

- 2010. "Boasian Ethnography and Contemporary Intellectual Property Debates." Proceedings of the American Philosophical Society 154 (1): 40-49. http:/ / www.jstor.org/stable/20721526.

- 2013a. "The Story of Colonialism, or Rethinking the Ox-Hide Purchase in Native North America and Beyond." The Journal of American Folklore 126 (499): 31-54.

- 2013b. Yuchi Folklore: Cultural Expression in a Southeastern Native American Community. Norman: University of Oklahoma Press.

Jakobson, Roman. 1960. "Closing Statement: Linguistics and Poetics." In Style in Language, edited by Thomas A. Sebeok, 350-77. Cambridge: MIT Press.

—. 1980. "Metalanguage as a Linguistic Problem." In The Framework of Language, 81-92. Ann Arbor: Graduate School, University of Michigan.

Kirshenblatt-Gimblett, Barbara. 1995. "Theorizing Heritage.” Ethnomusicology 39

(3): 367-80. http://www.jstor.org/stable/924627.

- 1998. "Sounds of Sensibility." Judaism 47 (1): 49-78.

. 2004. "Intangible Heritage as Metacultural Production." Museum International56 (1-2):52-65.http://dx.doi.org/doi:10.1111/j.1350-0775.2004 .00458.x.

- 2006. "World Heritage and Cultural Economics." In Museum Frictions: Public Cultures/Global Transformations, edited by Ivan Karp, 161-202. Durham: Duke University Press.

Kroeber, Alfred L. 1948. Anthropology: Race, Language, Culture, Psychology, Prehistory. New York: Harcourt, Brace, and Company.

Kuutma, Kristin. 2013. "Between Arbitration and Engineering: Concepts and Contingencies in the Shaping of Heritage Regimes.” In Heritage Regimes and the State. Göttingen Studies in Cultural Property, 6, edited by Regina Bendix, Aditya Eggert, and Arnika Peselmann, 21-36. Göttingen: Universitätsverlag Göttingen. http://resolver.sub.uni-goettingen.de/purl?isbn-978-3-86395-122-1.

— 2016. "From Folklore to Intangible Cultural Heritage." In A Companion to Heritage Studies, edited by William Logan, Máiréad Nic Craith, and Ullrich Kockel, 41-54. Malden, MA: John Wiley and Sons.

Lowie, Robert. 1940. An Introduction to Cultural Anthropology, 2nd ed. New York: Farrar and Rinehart.

Mauss, Marcel. 1979. "Body Techniques." In Psychology and Sociology, translated by Ben Brewster, 97-123. London: Routledge and Kegan Paul. 
Maags, Christina and Marina Svensson, eds. 2018. Chinese Cultural Heritage in the Making: Experiences, Negotiations, and Contestations. Amsterdam: Amsterdam University Press.

Merriam-Webster. 2018. "Model." Accessed August 7, 2018. Merriam-Webster.com. https://www.merriam-webster.com/dictionary/model.

Moore, Robert E. 2008. "Endangered." Journal of Linguistic Anthropology 9 (1-2): 65-68. https://doi.org/10.1525/jlin.1999.9.1-2.65.

Müske, Johannes. 2015. Klänge als Cultural Property: Technik und die kulturelle Aneignung der Klangwelt [Sounds as cultural property: Technology and the cultural appropriation of the soundworld]. Zürich: Chronos. https://doi.org /10.5167/uzh-111069.

Noyes, Dorothy. 2003. Fire in the Plaça: Catalan Festival Politics After Franco. Philadelphia: University of Pennsylvania Press.

- 2014. "From Heritage to Sustainability to Resilience: Compromised Concepts in Rising Waters." Paper presented at the colloquium "Sustainable Pluralism: Linguistic and Cultural Resilience in Multiethnic Societies." The Mershon Center for International Security Studies, The Ohio State University. September 5, 2014.

- 2016. Humble Theory: Folklore's Grasp on Social Life. Bloomington: Indiana University Press.

Rogers, Everett M. 2003. Diffusion of Innovations, 5th ed. New York: Free Press.

Shuman, Amy, and Galit Hasan-Rokem. 2012. "The Poetics of Folklore." In $A$ Companion to Folklore, edited by Regina F. Bendix and Galit Hasan-Rokem, 55-74. Malden, MA: Blackwell.

Silverstein, Michael. 1979. "Language Structure and Linguistic Ideology." In The Elements: A Parasession on Linguistic Units and Levels, edited by Paul R. Cline, William F. Hanks, and Carol L. Hofbauer, 193-247. Chicago: Chicago Linguistic Society.

— 1981. "The Limits of Awareness." Sociolinguistic Working Paper, 84. https:// eric.ed.gov/?id=ED250941.

SIEF (Société Internationale d'Ethnologie et de Folklore). 2014 "What is European Ethnology?" Accessed May 17, 2018. https://www.siefhome.org/videos /euro_ethno.shtml.

—. 2017. "What Do Ethnologists Do?" Accessed May 17, 2018. https:// vimeo.com/237142052.

Skrydstrup, Martin. 2012. "Cultural Property." In A Companion to Folklore, edited by Regina F. Bendix and Galit Hasan-Rokem, 520-36. Malden, MA: Blackwell.

Stocking, George W., ed. 1998. Volksgeist as Method and Ethic: Essays on Boasian Ethnography and the German Anthropological Tradition. Madison: University of Wisconsin Press.

Swedberg, Richard. 2017. "How to Use Max Weber's Ideal Type in Sociological Analysis.” Journal of Classical Sociology, December 8, 2017, 1468795X17743643. https://doi.org/10.1177/1468795X17743643.

Tauschek, Markus. 2011. "Reflections on the Metacultural Nature of Intangible Cultural Heritage." Journal of Ethnology and Folkloristics, 5 (2): 49-64. Accessed October 1, 2018. http://www.jef.ee/index.php/journal/article/view/76/0. 2013. Kulturerbe: Eine Einführung. Berlin: Reimer.

UNESCO. 2018. "Fujian Tulou.” Accessed May 31, 2018. https://whc.unesco.org /en/list/1113. 
Urban, Greg. 2001. Metaculture: How Culture Moves through the World. Minneapolis: University of Minnesota Press.

Weber, Max. 1949. The Methodology of the Social Sciences, edited and translated by Edward Shils and Henry A. Finch. Glencoe, IL: Free Press.

Yasunobu Ikeda. 2015. "Apple-Watch Sport." Flikr. https://www.flickr.com /photos/clockmaker-jp/17111109088.

Zhang, Lijun. 2014. "Living with/in Heritage: Tulou as Home, Heritage, and Destination.” PhD diss., Indiana University.

- 2018. "Presentation, Representation, and Museumification in Heritage Tourism: The Case of Hongkeng Hakka Earth Building Folk Cultural Village.” Museum Anthropology Review 12 (1): 5-13. https://doi.org/10.14434 /mar.v12i1.20731.

JASON BAIRD JAGkson is a Professor of Folklore and Anthropology at Indiana University. He is the author of Yuchi Folklore: Cultural Expression in a Southeastern Native American Community (Norman: University of Oklahoma Press, 2013) and editor of the Material Vernaculars book series published by Indiana University Press. (jbj@indiana.edu)

JohAnnes Müske is a research associate and lecturer at the Center for Popular Culture and Music and the Institute for Cultural Anthropology and European Ethnology at the University of Freiburg. He is the author of Klänge als Cultural Property: Technik und die kulturelle Aneignung der Klangwelt (Zürich: Chronos, 2015). (johannes .mueske@kaee.uni-freiburg.de)

Lijun Zhang is an Assistant Professor of Folklore at George Mason University. With Ziying You, she is the co-editor of Chinese Folklore Studies Today (Bloomington: Indiana University Press, 2019) and, with Marsha MacDowell, Quilts of Southwest China (Nanning: Guangxi Museum of Nationalities, 2016). (lzhang31@gmu.edu) 
Copyright of Journal of Folklore Research is the property of Indiana University Press and its content may not be copied or emailed to multiple sites or posted to a listserv without the copyright holder's express written permission. However, users may print, download, or email articles for individual use. 